\title{
Early Chemistry Misconceptions: Status and Implication on Quality of Primary Education in Ethiopia
}

\author{
Abayneh L. Gurmu \\ Lecturer, Fitche College of Teachers Education, Fitche, Addis Ababa/Ethiopia
}

\begin{abstract}
Misconceptions towards basic chemistry concepts have been identified at all level of chemistry education in recent studies. Such set of early misconceptions about very basic chemistry concepts were even found to be reflected by pre service and experienced in-service teachers. This implies that numerous set of chemical misconceptions kept cycling in the entire educational system. As a result, the entire science educational system is being blamed of producing learners with numerous misconceptions and low conceptual understanding. In fact, the alarmingly declining students' performance in regional and national examination in Ethiopia (NOE, 2010), for example, could be an indicator of this situation. Moreover, such quality threatening issues are not getting fair stakeholders' emphasis especially in Ethiopia. It was aimed, therefore, to discuss the status of early misconceptions and its implications.
\end{abstract}

Keywords: Chemical misconceptions, alternative conceptions, diagnostic studies, basic concepts and conceptual change

\section{General BaCkground}

\subsection{Meaning of Misconception}

Learners could have number of preconceptions about a given scientific phenomena (Taber, 2002; Temechegn, 2002; Yasin, 2004). Some of these preconceptions are in conflict with the scientific view (Kind, 2004; Yasin, 2004). Preconceptions which are in conflict with the scientific view are called misconceptions. Such preconceptions are also called students' conceptions (Taber, 2002;Yasin, 2004), children's science (Al-Rubayea, 1996; Gilbert et al... 1982), alternative conceptions or alternative ideas (Garnet et al,1995; Gilbert \& Watts, 1980; Sileshi \& Barke, 2007; Taber, 2002; Temechegn, 2002; Wandersee et al., 1994), and as mistakes (Boujaude, 1992; Kind, 2004), errors (Bimbola,1988; Boujaude, 1992; Kind, 2004), misunderstandings (Boujaude, 1992; Kind, 2004), misleading beliefs (Reynolds, 1992), misinterpretation of facts (Gilbert et al., 1982), and as private concepts (Krause, et al., 2004), naive theories and naive conceptions or naive knowledge (Temechegn, 2002; Yasin 2004), and as commonsense beliefs (Hihnston \& Scott,1991; Reynolds, 1992).

However, it is important to understand that not all preconceptions are misconceptions. It is also necessary to underline that a misconception is not a mistake and it does not stem from lack of knowledge (Abayneh, 2012; Kind, 2004; Taber, 2002). Rather, misconception is the understanding of a concept in a wrong or missing way. If a student has a misconception, his/her conception is not true or missing whereas it is true for himself/herself. Although it is wrong, it works for the student (Abayneh, 2012; Taber, 2002; Yasin, 2004).

\subsection{History of Diagnostic Researches}

Exploring students' misconception in science started as a research at late 1970s, and became more prominence at early 1980s (Taber, 2013). During this period, as briefly stated by Taber (2009), research groups based at the Universities of Waikato (New Zealand), Leeds (UK) and Surrey (UK) undertook extensive programs of research into children's ideas in science, and a range of seminal studies were published. These studies effectively initiated a research programs into the nature of children's ideas, how they developed and how teachers should respond (Taber, 2009).

The program was underpinned by a perspective on learning that is commonly referred to as constructivism. The interest in this area of research led to a number of books on children's ideas in science (Kind, 2004; Taber, 2009). It was also this publication that brings the issue of diagnostic 
researches and respective remedies in to other European and Asians countries like Germany (Barke et al., 2007), Israel (Levy et al., 2004), Turkey (Yasin, 2004) and Oman (Suleiman et al., 2012).

In Ethiopia, it was the introduction of a new 'Master of Science Education (M.Ed)' post graduate program that exposed most post graduate students to the idea of students' alternative conceptions. In fact, few distinguished diagnostic studies have been carried out before. For instance, Temechegn (2002) carried out remarkable diagnostic studies and came up with some conceptual change strategies. But, after the introduction of the new M.Ed program, significant number of studies are being carried out by both former researchers (Sileshi, 2011; Sileshi \& Barke, 2007) and postgraduate students (Abayneh, 2012) of which some of them were published. Still, the problem in our context is that most of the studies were found to focus only on higher level chemistry concepts, almost leaving the basic and fundamental concepts untouched (Abayneh, 2013b).

\subsection{Identification of Misconception}

It is important to know what prior knowledge students bring to learning environment in order to help them to construct new knowledge (Taber, 2009; Temechegn 2002, Yasin, 2004). In the past and still at present in our country, students' prior knowledge was not considered seriously (Abayneh, 2012, 2013b, 2013b). When misconception diagnostic studies started to appear in the literature, science educators have focused on developing valid and reliable methods to identify them. Therefore, variety of methods to identify students' misconceptions are being proposed and examined for their effectiveness. These include interviews (Kind, 2004; Kuiper, 1994; Osborne \& Gilbert, 1982; Posner \& Gartzog, 1982), word associations (Kuiper 1994), open-ended questions (Beicher, 1994; Osborne \& Gilbert, 1982), multiple-choice test (Al-Rubayea, 1996; Rolling \& Mohooana, 1999), multiple-choice test with explanation (Al-Rubayea, 1996; Rolling \& Mohooana, 1999; Yasin, 2004), two-tier multiple choice test (Al-Rubayea, 1996; Griffard \& Wandersee, 2001) and three-tier multiple choice test (Griffard \& Wandersee, 2001; Yasin 2004)

Here, it should be noted that, each of the above diagnostic instruments has its own strength and drawback. For instance, interview and open-ended test enable us to get in-depth information on students' pre and existing conceptions (Krause, 2004; Osborne \& Gilbert, 1982). But, they are disadvantageous for being time consuming to interview large number of students to get greater generalizability. Moreover, these methods also require additional training of researchers (Yasin, 2004).

On the other hand, multiple choice test is very helpful in that it can easily be prepared, administered and scored (Al-Rubayea, 1996). However, such tests do not go deep enough inside into the students' ideas on the topic and students very often give correct answers for wrong reasons. Also, multiplechoice tests were found to direct the students' attention on information in isolation by testing one element at a time. Therefore, the larger context and structure of relationships between and among the elements get lost (Rolling \& Mohooana, 1999; Yasin, 2004). Such tests were also found to overestimate intensity of diagnosed misconceptions as they couldn't enable us identify misunderstanding (lack of understanding) from misconceptions (Abayneh, 2012; Yasin, 2004). In this regard, Abayneh (2012) found that one-tier test overestimates students' misconception by $12 \%$ while the two-tier test overestimates students' misconception by $8 \%$. This implies that diagnostic tests like multiple choice items and two-tier tests are less efficient in exactly figuring out the extent of students' misconceptions. As a result, such tests are not potential enough to discriminate misconception from lack of knowledge.

This overestimation problem can be maintained by adding a second and/or a third tier in to each item of the test by which the test becomes a two-tier or three-tier multiple choice test. In this regard, threetier multiple choice tests are very much effective in exactly identifying missed understanding from missed conception. Because, such tests enable us know confidence of participants in their answer. Hence, only if the respondents is enough confident in his/her choice, the suspected alternative conceptions is taken as misconceptions (Gilbert, et al., 1982; Yasin 2004).

Generally, it should be noted that each diagnostic instrument has its own advantages and drawbacks. So, there is no best (single) diagnostic instrument. As a result, the use of mixed diagnostic instruments was found to be more effective in most comparative diagnostic studies (Abayneh, 2012, Al-Rubayea, 1996; Yasin, 2004). In most cases, three-tier multiple tests incorporated with interview were found to be effective (Yasin, 2004). 


\section{EARLy ChEMistry MisconCEPTIONS}

As already mentioned above, early diagnostic studies which target students' conceptions about basic chemistry concepts have got less emphasis. It is only in recent studies that basic chemistry concepts have been getting more emphasis. In these days, however, it looks like that the target of most diagnostic studies is shifting from advanced concepts entertained at higher education in to fundamental and basic concepts entertained in primary education (Abayneh, 2013b; Barker, 2000, Kind, 2004; Sileshi \& Barke, 2007). Because, it was being found that these early misconceptions about basic and fundamental chemistry concepts have been diagnosed in primary, secondary and tertiary education (Abayneh, 2013b, 2013b; Suleiman et al., 2012). In this section, status of early misconceptions, commonly observed misconceptions and basic concepts which are more susceptible to misconceptions are briefly discussed as follows.

\subsection{Over all Status of Early Misconception}

Most of the conducted diagnostic inquiries were found to target more complex and advanced chemical concepts which are entertained at tertiary education. As a result, wide range of chemical misconceptions towards more advanced and complex concepts were found. In looking for remedial solutions, through further studies, some researchers suspected that those college, university students, and even teachers could have misconceptions not only about the advanced chemical concepts but also, about those very basic chemical concepts from the very beginning which they have learnt in primary education before many years (Barker, 1994; Lee et al., 1993; Peterson \& Treagust, 1989). Consequently, many early diagnostic studies have been conducted and numerous $11-16$ years students' misconceptions were accordingly found (Abraham \& Wilkinson, 1994; Barker, 2000; Kind, 2004; Taber, 2002). In this regard, a general concepts inventory review was also came up with a detailed list of existing students' misconceptions and suggested implication, and made available for further interventions (Kind, 2004; Taber, 2002).

In Ethiopia too, similar diagnostic studies revealed that junior students have variety of misconceptions about the very basic chemical concepts (Sileshi, 2011; Temechegn, 2002). Besides, from baseline survey of USAID/IQPEP Ethiopia and national learning assessment report, it was hypothesized that presence of such intense students' early misconceptions might be one possible source of the alarmingly declining students' science performance in regional and national examinations (USAID/IQPEP, 2011; NOE, 2010). Some diagnostic studies carried out abroad also found to support such hypothesis. As a result, diagnostic comparative studies focuses only on basic chemistry concepts were being carried out on primary and secondary students, pre-service teachers (college and university students), in-service primary and secondary teachers (Abayneh, 2013b, 2013b; Haidar, 1997; Kind, 2009; Muireann et al., 2013; Suleiman et al., 2012).

Muireann et al. (2013), for example, found that Irish pre-service teachers have as equivalent proportion of chemical misconception as before they join the university. In their comparative and consecutive studies, they administered the same diagnostic tests each year starting from first year to the same students. Finally, they found that the same set of misconceptions diagnosed at first year still exist on the graduate teachers' mind even after years of trainings.

Besides, Abayneh (2013b) carried out a comparative diagnostic study by which eighth grade students and their chemistry teachers were allowed to take a multi-tier chemistry misconception test and attend a semi structured interview. At the end, the correlation of intensity and areas of both students' and teachers' misconceptions about basic chemical concepts was found to be significant, average of 0.86 . On the other hand, a diagnostic study (on eighth grade students and pre-service chemistry teachers misconception about chemical and physical changes) carried out by the same author revealed that those college graduates have almost similar set and magnitude of misconceptions about such basic and simple chemical concepts (Abayneh, 2013b).

Generally, findings of all the comparative studies shows that those early misconceptions about basic chemical concepts are dominantly found at any level and remaining in the entire educational system (Abayneh, 2013b, 2013b; Kind, 2009; Suleiman et al., 2012).

\subsection{Basic Chemical Concepts Mostly Susceptible to Misconceptions}

Recent diagnostic studies carried out on early misconceptions revealed that some basic chemical concepts are more susceptible to alternative conception than others (Abayneh, 2013b; Barker, 2000; Suleiman et al., 2012). As per the findings of these diagnostic studies, particulate nature of matter 


\section{Abayneh L. Gurmu}

(Abayneh, 2012; Barker, 2000; Mulford \& Robinson, 2002; Temechegn, 2002), physical state of matter (Barker, 2000; Sileshi \& Barke, 2007; Suleiman et al., 2012), chemical and physical changes (Abayneh, 2013b; Lee, et al., 2004), phase changes (Abayneh, 2013; Barker, 2000; Kruse \& Roehrig, 2005) and stoichiometry (Barker, 2000; Sileshi, 2011; Suleiman et al., 2012) are among the most susceptible basic chemistry concepts.

\subsection{Commonly Observed Chemistry Early Misconceptions}

Sets of wide range of misconceptions and naïve ideas towards these basic concepts were diagnosed and documented by respective researchers. From these, misconceptions commonly observed are summarized in the table below with source of documented studies.

Table1. Commonly Observed Chemistry Early Misconceptions

\begin{tabular}{|c|c|}
\hline Diagnosed Misconceptions & References \\
\hline \multicolumn{2}{|l|}{ Phase Change, Physical and Chemical Changes } \\
\hline Water (in puddles) will disappear to nothing when exposed to sun ray. & Barke, 2009; Barker, 2000 \\
\hline $\begin{array}{l}\text { Water decomposes to } \mathrm{H} \text { and } \mathrm{O} \text { during evaporation (or the water will split } \\
\text { up into millions of tiny micro bits and floated up). }\end{array}$ & $\begin{array}{l}\text { Kind (2004), Barker(2000); } \\
\text { Abayneh (2013b) }\end{array}$ \\
\hline Water contain hydrogen and oxygen molecule in it. & Barke (2009), Abayneh (2013b) \\
\hline When a stick is broken, the bonds at the broken area will also be broken. & Suleiman et al. (2012) \\
\hline $\begin{array}{l}\text { Volume of gases increases up on heating because of the swelling of their } \\
\text { molecules, or vice versa (decrease because of shrinking). }\end{array}$ & Barke (2009), Abayneh (2013b) \\
\hline Sugar disappears up on dissolving. & $\begin{array}{l}\text { Happs (1980) in Kind (2004), } \\
\text { Abayneh (2013b) }\end{array}$ \\
\hline Sugar turns to water up on dissolving. & $\begin{array}{l}\text { Kind (2004), Abayneh (2013b), } \\
\text { Barker (2000) }\end{array}$ \\
\hline Sugar decomposes to its elements up on dissolving in water. & $\begin{array}{l}\text { Kind (2004), Abayneh (2013b), } \\
\text { Barker (2000) }\end{array}$ \\
\hline Nail melts when exposed to moisture and air. & $\begin{array}{l}\text { Kind (2004), Abayneh (2013b), } \\
\text { Barker (2000) }\end{array}$ \\
\hline Nail dissolves when exposed to moisture and air. & $\begin{array}{l}\text { Kind (2004), Abayneh (2013b), } \\
\text { Barker (2000) }\end{array}$ \\
\hline $\mathrm{CdCl}_{2}$ is toxic like $\mathrm{Cd}$ metal. & $\begin{array}{l}\text { Kind (2004), Abayneh (2013b), } \\
\text { Barker (2000) }\end{array}$ \\
\hline The chemical composition of flame of a burning candle is just flame. & $\begin{array}{l}\text { Kind (2004), Abayneh (2013b), } \\
\text { Barker (2000) }\end{array}$ \\
\hline $\begin{array}{l}\text { The chemical compositions of flame of a burning candle are dust } \\
\text { particles. }\end{array}$ & $\begin{array}{l}\text { Abayneh (2013b, 2013b),Barker } \\
(2000)\end{array}$ \\
\hline $\begin{array}{l}\text { The chemical composition of flame of a burning candle is gases like } \\
\text { Oxygen, hydrogen, carbon dioxide and so on. }\end{array}$ & $\begin{array}{l}\text { Abayneh (2013b, 2013b),Barker } \\
(2000)\end{array}$ \\
\hline The iodine crystal will melt up on heating. & $\begin{array}{l}\text { Kind (2004), Barker (2000), } \\
\text { Abayneh (2013b) }\end{array}$ \\
\hline $\begin{array}{l}\text { The iodine molecule }\left(\mathrm{I}_{2}\right) \text { decomposes to its constituent atoms up on } \\
\text { sublimation. }\end{array}$ & $\begin{array}{l}\text { Kind (2004), Abayneh (2013b), } \\
\text { Barker (2000) }\end{array}$ \\
\hline Benzene disappears when left open. & $\begin{array}{l}\text { Kind (2004), Abayneh (2013b), } \\
\text { Barker (2000) }\end{array}$ \\
\hline \multicolumn{2}{|l|}{ Particulate Nature or Properties of Matter } \\
\hline $\begin{array}{l}\text { Atom is like some kind of billiard object fully filled throughout by some } \\
\text { other particles. }\end{array}$ & Abayneh (2013b), Kind (2004) \\
\hline Atom of an element can be seen through microscope. & Abayneh (2013b), Kind (2004 \\
\hline $\begin{array}{l}\text { Atom of an element have physical state and color, density, melting point } \\
\text { and so on like any other form of matter }\end{array}$ & $\begin{array}{l}\text { Muireann et al. (2013), Barker } \\
\text { (2000), Abayneh (2013b) }\end{array}$ \\
\hline Atoms of elements exist in liquid state & Abayneh (2013b), Kind (2004) \\
\hline $\begin{array}{l}\text { Space between an atom and a molecule is filled with dust particles, } \\
\text { germs and bacteria. }\end{array}$ & $\begin{array}{l}\text { Kind (2004), Barker (2000), } \\
\text { Abayneh (2013b) }\end{array}$ \\
\hline Matter is not conserved as gases weighs less than solid & Muireann et al. (2013) \\
\hline $\begin{array}{l}\text { Matter has no permanent aspect. When matter disappears from sight } \\
\text { (example, when sugar dissolves in water) it ceases to exist. }\end{array}$ & Kind (2004) \\
\hline $\begin{array}{l}\text { Matter has a materialistic core to which various random properties } \\
\text { having independent existence are attached. Matter can disappear, } \\
\text { whereas its properties (such as sweetness) can continue to exist } \\
\text { completely independently of it. }\end{array}$ & Kind (2004) \\
\hline
\end{tabular}


Early Chemistry Misconceptions: Status and Implication on Quality of Primary Education in Ethiopia

\begin{tabular}{|c|c|}
\hline $\begin{array}{l}\text { Weight is not an intrinsic property of matter. The existence of weightless } \\
\text { matter can be accepted. }\end{array}$ & Kind (2004) \\
\hline $\begin{array}{l}\text { Simple physical transformations (such as dissolution are not grasped as } \\
\text { reversible. }\end{array}$ & Kind (2004) \\
\hline \multicolumn{2}{|l|}{ State of Matter } \\
\hline $\begin{array}{l}\text { A single } \mathrm{H}_{2} \mathrm{O} \text { molecule has different shape and structure in solid, liquid } \\
\text { and gaseous state. }\end{array}$ & Abayneh (2013b) \\
\hline River water and ice water are different in their chemical composition. & Abayneh (2013b) \\
\hline Molecules (particles) of water can experience motion only in liquid state. & Abayneh (2013b) \\
\hline $\begin{array}{l}\text { Some solids decompose, change slowly into some other (useless) } \\
\text { substance; or mature, change slowly into some other (useful) substance. }\end{array}$ & Kind (2004) \\
\hline $\begin{array}{l}\text { Stuffs like iron, water, wood, meat, stone and sand exist in different } \\
\text { kinds of physical state: solid, liquid, powder, paste, jelly, slime and } \\
\text { paper-like. }\end{array}$ & $\begin{array}{l}\text { Kind (2004), Barker (2000), } \\
\text { Abayneh (2013b) }\end{array}$ \\
\hline \multicolumn{2}{|l|}{ Stoichiometry } \\
\hline $2 \mathrm{H}_{2}$ and $\mathrm{H}_{4}$ are the same in every aspect. & $\begin{array}{l}\text { Abayneh (2013b), Sileshi \& } \\
\text { Barke, 2007), Sileshi (2011) }\end{array}$ \\
\hline $2 \mathrm{NH}_{3}$ and $\mathrm{N}_{2} \mathrm{H}_{6}$ are the same too! & Abayneh (2013b) \\
\hline All the reacting species combine together whatever their proportion is. & $\begin{array}{l}\text { Abayneh (2013b), Sileshi \& } \\
\text { Barke, 2007), Sileshi (2011) }\end{array}$ \\
\hline The mass of all products of burning wood is less than that of the wood. & $\begin{array}{l}\text { Abayneh (2013b), Sileshi \& } \\
\text { Barke, 2007), Sileshi (2011) }\end{array}$ \\
\hline Most of the mass of a large tree comes from soil. & Sileshi \& Barke, 2007) \\
\hline $\begin{array}{l}\text { The weight of a metal remains the same after combustion (ignoring the } \\
\text { role of oxygen). }\end{array}$ & $\begin{array}{l}\text { Acar \& Tarha (2007), Suleiman } \\
\text { et al. (2012), Hihnston \& Scott } \\
\text { (1991) }\end{array}$ \\
\hline $\begin{array}{l}\text { When gases are produced from combustion reaction of a liquid and solid, } \\
\text { the total mass decrease, even if a system is closed. }\end{array}$ & Suleiman et al. (2012) \\
\hline $\begin{array}{l}\text { The mass of magnesium strip is greater than that of magnesium oxide } \\
\text { which is formed after burning of the magnesium strip. }\end{array}$ & Suleiman et al. (2012) \\
\hline Magnesium strip loses parts of its mass as energy up on combustion. & Suleiman et al. (2012) \\
\hline $\begin{array}{l}\text { The mass of water remains constant before and after a sugar is dissolved } \\
\text { in it, whatever the mass of the sugar is (as if the sugar was just } \\
\text { disappeared or lost). }\end{array}$ & $\begin{array}{l}\text { Abayneh (2013b), Sileshi \& } \\
\text { Barke, 2007), Sileshi (2011) }\end{array}$ \\
\hline $\begin{array}{l}\text { The mass of the rust is greater than that of the nail because of addition of } \\
\text { soil. }\end{array}$ & $\begin{array}{l}\text { Abayneh (2013b), Sileshi \& } \\
\text { Barke, 2007), Sileshi (2011) }\end{array}$ \\
\hline $\begin{array}{l}\text { The mass of the rust is less than that of the nail because the nail is just } \\
\text { eaten up. }\end{array}$ & $\begin{array}{l}\text { Abayneh (2013b), Sileshi \& } \\
\text { Barke, 2007), Sileshi (2011) }\end{array}$ \\
\hline The mass of the rust is equal to that of the nail. & $\begin{array}{l}\text { Abayneh (2013b), Sileshi \& } \\
\text { Barke, 2007), Sileshi (2011) }\end{array}$ \\
\hline
\end{tabular}

\subsection{Implication of Early Misconceptions on Quality of Primary Education}

\section{Implication for Primary Education}

Dominance of these misconceptions about the very basic chemistry concepts in the entire educational system implies that there is some king of gap, especially in primary education as most of these concepts are introduced and presented in higher primary education. The gap could mainly be in terms of ways of subject delivery, nature and organization of the subject contents and teachers' competencies as all these were found to be most influential source of misconceptions (Kind, 2004; Taber, 2009; Temechegn, 2009).

In this regard, such dominance implies that our primary educational system enhance only memorization of terminology and definitional description. It is not giving a chance for children to observe, examine and feel the chemical phenomena beyond each learnt concept, and share, compare and evaluate their own existing understanding with others (Kind, 2004; USAID/IQPEP, 2011). It rather implies that, our primary education assessment system could not identify students with desired and alternative conceptions. This, in turn, implies that our assessment activities are not incorporating diagnostic tests. Generally, existence of such wide range and intense alternative conceptions implies that diagnosis-based educational assessment and misconceptions curing instructional system are not totally being incorporated and practiced in the existing curriculum. As a result, our primary education system could not give chance, responsibility and competency to teachers to employ continuous 
diagnosis-based assessment and misconceptions curing instructional activities. It should be noted, therefore, that this ignorance is obviously endangering the quality of our primary education.

\section{Overall Implication}

Even though, most of alternative conceptions are found in primary education, it was still being found that high school, college, university students and even in-service teachers have the same set of alternative conceptions about very basic chemistry concepts (Abayneh, 2013b, 2013b; Haidar, 1997; Kind, 2009; Muireann et al., 2013; Nakiboglu, 2003). This means that, having all these set of alternative conceptions, primary students are being able to join high schools and higher learning institutions. Moreover, they are even being able to pass higher education entrance, school leaving and teaching competency national examinations without any problem.

As a result, it could clearly and unfortunately be understandable that our entire educational evaluation and assessment system fails to at least identifying children/students/nominees/graduates with desired, alternative and no conceptions. Having felt this failure, one can realize that diagnostic type items remains ignored in our entire educational system ranging from a specific classroom level formative assessment up to a national teaching competency summative evaluation. This failure in turn implies that dominance recycling of early misconceptions is further endangering quality of our overall education.

\section{CONCLUSION AND RECOMMENDATIONS}

In this review, it was attempted to figure out how serous early misconceptions are dominantly recycling in our educational system. It also found logical that the entire educational assessment and evaluation system fails to identify learners with desired, alternative and no conceptions. This means that both our formative and summative assessment tools employed at all level are not incorporating diagnostic type instruments. Here comes the problem! This does mean that, our educational system is not entertaining the issues of concept inventory and respective curing: no much awareness and hence, no consideration at all.

Therefore standing on this base, it is not feasible to even think about the remedial interventions. Because awareness and fair emphasis need to be worked on first. Hence, those well exposed science educators and researchers need to struggle towards exposing the risk of dominancy of alternative conceptions and creating respective awareness. On the other hand, the most influential stakeholders (like policy makers, curriculum experts, educational assessment and competency specialist and authorities) needs to take a breath, listen to our findings and think about it.

In doing so, the issues of diagnostic type instruments are going to be entertained in respective assessment and evaluation process. It is only in this way that we will be fortunate to make continuous diagnostic assessment and misconception curing instructional strategies part of our entire educational system. In this way, we will be courageous enough to look for, employ experiments and choose the most updated diagnostic and other curing strategies like some educationally distinguished countries.

\section{REFERENCES}

Abayneh Lemma (2012). Diagnosing the diagnostics: Misconceptions of twelfth grade students on selected chemistry concepts in two preparatory Schools in eastern Ethiopia. African Journal of Chemical Education, 2(2). http://www.faschem.org/index.php.

Abayneh Lemma (2013a). A diagnosis of eighth grade students' and pre-service teachers' misconceptions about physical and chemical change, unpublished and under review by Science Education International.

Abayneh Lemma (2013b). A diagnostic assessment of eighth grade students' and their teachers' misconceptions about basic chemical Concepts. African Journal of Chemical Education, 3(1). http://www.faschem.org/index.php.

Abraham, M.R., \& Wilkinson, V.M (1994). A cross-age study of the understanding of five chemistry concepts. Journal of Research in Science Teaching 31, 147

Al-Rubayea, A. A. M. (1996). An analysis of Saudi Arabian high school students' misconceptions about physics concepts in Yasin, K. (2004), a M.Sc. dissertation thesis report. M. Sc. Thesis report, Middle East Technical University. 
Barker, V. (1994). An investigation of 16-18 year old students' understanding of basic chemical ideas. In P. L. Lijnse (Ed.), European research in Science Education- Proceedings of the first Ph. D. Summer school (pp. 175-183). Utrecht: CDß Press, Centrum voor ß-Didactiek.

Barker, V. (2000). Students' misconceptions about basic chemical ideas. A report prepared for the Royal Society of Chemistry. London WC1H OAL.

Bimbola, I.O. (1988). The problem of terminology in the study of students' conceptions in science. Science Education 72, 175.

Boujaude, E. B (1992). The relationship between students' learning strategies and the change in their misunderstandings during a high school chemistry course. Journal of Research in Science Teaching 29, 687.

Coll, R.K \& Treagust, D.F. (2003). Investigation of secondary school, undergraduate, and graduate learners' mental models of ionic bonding. Journal of Research in Science Teaching, 40(5), 464486

Garnett, P., Garnett, P. \& Hackling, M. (1995). Students' alternative conceptions in chemistry: A review of research and implication for teaching and learning. Research in Science Education 25, 69.

Gilbert, J.K., Osborne, R.J. \& Fensham, P.J. (1982). Children's science and its consequence for teaching. Studies in Science Education 66, 623.

Gilbert, J.K. \& Watts, D.M (1980). Concepts, misconceptions and alternative conceptions: Changing perspectives in science education. Research in Science Education 10, 61

Haidar, A.H. (1997). Prospective Chemistry Teachers' Conceptions of the Conservation of Matter and Related Concepts. Journal of Research in Science Teaching, 34(2), 181-197.

Hihnston, K. \& Scott, P. (1991). Diagnostic teaching in the classroom: Teaching - learning strategies to promote concept development in understanding about conservation of mass and on dissolving. Research in Science and Technology Education 9, 193

Holt-Reynolds, D. (1992). Personal History-Based Beliefs as Relevant Prior Knowledge in Course Work. American Educational Research Journal, 29(2), 325-349.

Kind, V. (2004). Beyond appearances: Students' misconceptions about basic chemical ideas, $2^{\text {nd }}$ ed., London: Royal Society of Chemistry.

Kind, V. (2009). A Conflict in Your Head: An exploration of trainee science teachers' subject matter knowledge development and its impact on teacher self-confidence. International Journal of Science Education, 31: 11, 1529 - 1562.

Krause, S., Birk, J., Bauer, R., Jenkins, B. \& Pavelich, M.J. (2004). Development, testing, and application of a chemistry concept inventory. Proceedings - Frontiers in Education Conference, FIE, 1 T1G-1.

Kruse, R.A. \& Roehrig, G.H. (2005). A Comparison Study: Assessing Teachers' Conceptions with the Chemistry Concepts Inventory. Journal of chemical education, 82(8), 1246-50.

Kuiper, J. (1994). Student ideas of science concepts: Alternative frameworks? International Journal of Science Education 16, 279.

Lee, O., Eichinger, D., Anderson, C., Berkheimer, G. \& Blakeslef, T. (1993). Changing middle school students' conceptions of matter and molecules. Journal of Research in Science Teaching 30, 249.

Levy, T., A., Hofstein, Mamlok, R. \& Bar-dov, Z. (2004). Can final examination amplify Students' misconception in Chemistry? Journal of Chemical education: Research and Practice Report, 71(4) 97-103.

Muireann S., Peter E. \& Sarah H. (2013). The Chemical Misconceptions of Pre-service Science Teachers at the University of Limerick: Do they change?

Mulford, D.R. \& Robinson, W.R. (2002). An inventory for alternate conceptions among first-semester general chemistry students. Journal of chemical education, 79(6), 739-44.

Nakleh, M.B. (1992). Why some students don't learn chemistry. Journal of Chemical Education 69, 191.

NOE, (2010). The Ethiopians Learning Assessment Report. Ministry of Education. www.NoE.org.et, downloaded October 2011. 
Osborne, R. \& Gilbert, J. (1980). A method for investigating concept understanding in science. European Journal of Science Education 2, 311.

Peterson, R.F. \& Treagust, D.F. (1989). Grade-12 Students' Misconceptions of Covalent Bonding and Structure. Journal of chemical education, 66(6), 459-60.

Posner, G.J. \& Gertzog, W.A. (1982). The clinical interview and the measurement of conceptual change. Science Education 66, 195.

Rollnick, M. \& Mahooana, P (1999). A quick and effective way of diagnosing student Difficulties: two tier from simple multiple choice questions in Yasin, K. (2005). Diagnosis of eleventh grade Misconception about Geometric Optics by a Three-tier test. Middle East Technical University.

Sileshi Yetbarek \& Barke, H.-D (2007). Chemistry Misconceptions: Evaluating and Remedies Based on Tetrahedral-ZPD Metaphor. Muenster 2007 (Paper presented at the 3rd Symposium of Chemistry Education, University of Muenster).

Sileshi Yetbarek (2011). Chemical reaction: Diagnosis and towards remedy of misconceptions. African Journal of Chemical Education, 1(1). http://www.faschem.org/index.php.

Suleiman M. Al-Balushi1, Abdullah K. Ambusaidi1, Ali H. Al-Shuailil \& Taylor, N. (2012). Omani twelfth grade students' most common misconceptions in chemistry Science Education International Vol.23, No.3, September 2012, 221-240.

Taber, K. (2002). Chemical Misconceptions: Prevention, Diagnosis and Cure. Volume I. London (Royal Society of Chemistry).

Taber, K. S. (2009). Challenging Misconceptions in Classroom: Resource to Support Teachers.

Temechegn Engida (2002). Students' alternative conception: Challenging the challenge, solutions: A biannual newsletter of the Chemical society of Ethiopia, Vol. 10, No. 1 \&2:11-14.

Treagust, D.F (1988). Development and use of diagnostic tests to evaluate students' misconceptions in science. Journal of Science Education 10, 159.

USAID/IQPEP Ethiopia (2011). Chemistry Teachers' Handbook and Experimental Manual for grade 7 and 8.

Wandersee, J.H., Mintzes, J.J. \& Novak, J.D (1994). Research on alternative conceptions in science. In Gabel, D.: Handbook of Research in Science Teaching and Learning. New York (Macmillan).

Yasin, K. (2004). Diagnosis of eleventh grade Misconception about Geometric Optics by a Three-tier test. M. Sc. Thesis report. Middle East Technical University. 